\title{
UNWRITTEN HISTORY OF BLOOMINGTON (NOW MUSCATINE) IN EARLY DAYS.
}

READ BY J. P. WALTON BEFORE THE MUSCATINE ACADLMY OF SCIENOE, MAKCH $6,1882$.

WHEN the newcomer stepped from the steamboat near the foot of Chestnut street he frequently stopped with Robert C. Kinney, whose hotel, the lowa House, was located on the west corner of Front and Chestnut streets.

It is said that a stranger stopped with him one night and in the morning asked landlord Kinney where he should wash, who, turning to his customer, inquired if he had a handkerchief, and receiving an affirmative answer, said: "Well, there is the river. Wash there and wipe on your handkerchief."

Bob Kinney, as he was called, commenced his hotel in 1836, by building the rear part, in size $20 \times 30$ feet, one and one-half stories ligh. This was undonbtedly the largest building in the city at that time. In a couple of years he had enlarged it by building on a front which had a two story porch extending its whole length. This porch was a very popular place for genteel loafing, the gentlemen using the lower porch and the upper one being reserved for the lady guests. This building was removed in 1880 after standing forty-four years. During the time of removing we observed the floor joist were mostly made of hewed black walnut logs, from eight to twelve inches in diameter and were quite sound. Bob. Kinney kept most of the bachelor boarders of our town, such as Hon. S. C. Hastings, Dr. Blaydes, Suel Foster and others. Kinney concluded at one time he would rent his tavern to a man by the name of Wm. Fry, commonly known as Captain Fry. Kinney thought he had better have a lease drawn up by a lawyer (they were all in debt to him for board). So he went to Hastings to get the lease made. He said he wanted a very strong one-one that would hold the "infernal regions." Hasting was his man. He, too, owed a board bill and was glad of a chance to square it in 
that way. He went to work, commeneing on his old English law forms and writing, rewriting, iterating and reiterating all the legal terms known in the calendar, until twenty pages of legal cap were written over. Kinney came in and the docnment was reiterated (Hastings says read) to his entire satisfaction. Hastings thus paid some $\$ 50$ of his board bill. This lease was used in renting to Fry. Kinney moved into a small building on Second street, near where Fische's hardware store now stands. Soon the country became too old for him, and he began to look for a newer one. One night about midnight he was taken very sick, and sent for Dr. C. O. Waters to come and see him. The doctor found him sitting up and refusing to go to bed. All he wanted of the doctor was to know if he knew anything about northwestern Texas. I don't know whether the doctor paid any back board or not by this visit. At all events the doctor was a bachelor at this time. Kinney shortly after left for Oregon, where he lived for many years. If the new-comer could not be accommodated at Kinney's, he would frequently stop at "Captain Jim's," the next hotel. It was where the postoffice now stands.

Captain James Parmer, known as "Captain Jim," was a large, rather fat, old man. He was a good customer at his own bar. Here is a sample of his advertisement in the Bloomington Herald of 1841.

\section{A PROCLAMATION.}

W HEREAS, I CAPT. JIM, long a dispenser of food to the hungry and a couch to the weary, as well as a "horn" to the dry, having taken pussession of that large and commodious house on Second street, Bloomington, Iowa, formerly the residence of His Hon. J. Williams, do hereby declare and make known to the world that I am now prepared at the sign of Capt. Jim, to accommodate those who may call upon me, in a satisfactory manner, otherwise they go scot free. That this statement may the more fully prove true, I hereby declare and make known that the following are my charges, for all of which the best the market can afford are furnished.

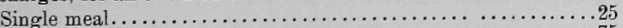

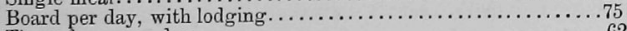

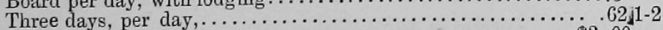

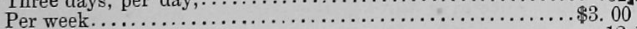

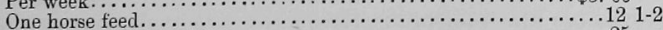

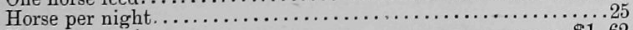

Horse per week .............................. 12 1-2

All other bills in proportion. I, the said Capt. Jim, do herehr f urther de- 
clare to those indebted to me for eating, sleeping, drinking, or upon contract of any kind whatsoever, that unless they come forward immediately and make settlement, Michael Scott was never in Scotland if I don 't send a constable after them to bring them to "taw;" so look out for Conklin or Ward.

Thankful for past favors, he hopes to receive a share of public patronage, corresponding with his efforts to minister to the tastes and render comfortable those who may favor him with their patronage.

Bloomington, Dec. 3, 1841.-6tf.

CAPT. JIM PARMER.

Pardon me for relating an anecdote told by Dan Rice, the noted showman. He says when he first started out he risited Bloomington and stopped with Captain Jim and had his exhibition at his hotel. Captain Jim insisted on having his pay in advance. But he compromised by making the Captain doorkeeper. At the close of the entertainment he reported no money. Dan inquired how that came. The Captain's reply was, he had so many friends that he had to invite whom he could not charge and thus he received no money. This left Dan six dollars in debt and no money to pay with. It is presumed this bill was never paid. We had still another hotel in town.

In the spring of 1839 Josiah Parvin occupied the old wooden building that stood on the corner of where Cook, Musser \& Co.'s Bank now stands and kept a hotel there until his new one was built, I think in 1840 , and which is now a part of the Eastern House on the west corner of Walnut and Second streets. Mr. Parvin was one of the best liearted men that ever came to a new country; too much so for his own good. He was very excitable and many amusing anecdotes are told of him. He was very fond of lhunting, like most of the Parvins, and while out hunting he once fell over a log, jumped up and commenced kicking himself with the following ejaculations: "Fall over a $\log$ ! Deserve to be kicked and I'll do it." So at it he went. Josiah Parvin set the best table and had the best boarders. Governor Lucas boarded there. Governor Dodge and Grimes were also among his patrons. Parvin's new hotel proved too much for him. He had to give it up as most of the occupants have since done, without taking away much money. 
A fourth hotel was started in the spring of 1841 by T. S. Battelle. It was located where Olds' Opera Huuse now stands. It was called the American House. This was the leading hotel in the place for a long time. During the winter season while the travel was suspended on the river and the old fashioned stage coach was made to take its place, this hotel was in its glory. It was no uncommon thing for a dozen stages to start out at a time all heavily loaded. In this hotel we saw our first cotillion danced in the winter of 1842-43. Here the first attempt was made to return a fugitive slave to slavery.

We are indebted to Mrs. S. E. Hughes and Mr. Alex Clark for most of the following particulars. A young colored boy, Jim White, belonged to Dr. Merry, who then lived on a farm about thirteen miles up the river. When Dr. Merry moved from St. Louis to Iowa he left this boy with his daughter, Mrs. Hughes, at St. Louis. Jim was hired on a steamboat on the lower Mississippi and was to have his freedom in two years. But he got into a fracas with the steward of the boat and got his head badly hurt, so he was sent North to Dr. Merry for treatment. He soon became so impudent that the doctor ordered him off the farm. Jim concluded he did not like country life and simply followed out the doctor's order. $\mathrm{He}$ left "Massa Merry" and came to town and commenced working at the hotel for Mr. James Borland, the proprietor at this time. The Merry family concluded that if Jim did not want to stay with the doctor he had better go to St. Louis, where he could be made available. Accordingly an officer from St. Louis was sent after Jim. He found him at the hotel and attempted to arrest him without judge or jury. Perhaps he would have succeeded if the proprietor, Mr. Borland, had not interfered. He disarmed the detective of his pistols by main force. In the mean time the boy took shelter with Mr. Clark, who had the St. Louis man arrested for kidnapping. One of our old citizens who is still residing here, Mr. Fred Phelps, went his security. The Merry family had the boy arrested according 
to law by one of our officers. Be was arraigned before D. C. Cloud, then a justice of the peace, with Stephen Whicher and R. P. Lowe for the prosecution and Jacob Butler, W. G. Woodward and J.S. Richman for the defense. The trial was held and the boy released on the ground that Dr. Merry had brought, or permitted the boy to come within the bounds of a free State, and which act freed the boy from all liability to be returned. This was before the noted Dred Scott decision. The boy was not safe, as the leading sonthern sympathizers were determined to take him without law. While the excitement was still high, an old fellow named Michael Greene went to Uncle Ben Mathews and Aunt Nellie, his mother, and said he was going to Chicago with a team and that he would take the boy with him. This was reported to Mr. Clark, who now had the boy snugly stowed away in his garret. It was arranged that Greene was to cross the river before night and go out to the third bridge and wait for the boy, who was to cross in a skiff as soon as it was dark. Mr. Clark, although not so old as he is now, was too smart to be gnlled by such an old rillain as Greene, he having known something of his previous record. Clark started as it was dark in company with the boy and two other persons to cross the river in a skiff. When out on the river so far as not to be noticed from the shore, they quietly let the skiff float down the river. They soon heard three different boats crossing above them. They quietly went home and went to bed. The parties in the other three boats spent the night in the bottom on the other side of the river looking through the woods after Jim, whom Mr. Clark had stowed away for the night. In the morning Greene returned without going to Chicago. After waiting for two or three days the St. Louis man conclnded he could not get Jim by stealth, so he went to Dubuque to obtain a warrant from a United States Judge for his arrest. It was generally understood that the U. S. Courts were intensely pro-slavery at this time and that Jim would stand a poor chance there. This pleased the 
pro-slavery side immensely, so much so they could not keep it secret. When the man got back from Dubuque, which occupied three or four days, Jim was arrested a second time. A writ of habeas corpus was obtained from Hon. S. C. Hastings, then acting Chief Justice of the Supreme Court of this State, who released him. Jim stayed around Bloomington, and joined the colored Methodist Church.

The American House was the stopping place for nearly all the traveling entertainments. In its earliest days but little else besides circuses came around. The artistic minstrel troupe did not make its appearance nntil after the old hotel had lost its prestige.

Mr. Battelle, the first proprietor, snceeded well in the hotel financially. He raised a large family, lost his wife and married Aunty, his wife's sister. Becoming dissatisfied with the hotel, he sold out and bought a steamboat, the Oswego. $\mathrm{He}$ lost considerable money trying to run it, and atter sinking the boat once or twice, finally left for Oregon.

In the rear of this hotel, where the Journal office now stands, was a frame building about $20 \times 40$ feet, originally built for a school house, but used by the Methodist Church. This building was also used for various purposes such as political conventions, lyceums and other public meetings. In this building we attended our first political meeting. Hon. G. W. Woodward was a candidate. We recollect seeing him there in a rough-looking costume, something remarkable for him. $\mathrm{He}$ was successful all the same.

In the winter of 1842-43 a lyceum was organized. Here the professional and non professional met in debate. We remember hearing a very interesting lecture from a prominent lawyer, followed by another on plagiarism. This lecture was remembered for years by both of them. I think they were exceptions to the ordinary lawyers. At another meeting one of the same lawyers got into a dispute, that ended in blows, with a doctor who is still living in this city. 
When the Methodist people built a new church (the present City Hall) and vacated the old building, it was converted into a stable.

In the year 1841, if I am correct, the Episcopal Society united with the Masons in erecting a church and a lodge room. This was the first building erected in this county for church purposes, the Masons occupying the npper or second story. The building was $22 \times 60$ feet and two stories. The lower or first floor was seated for church purposes, with high backed seats made of choice black walnut and painted white. This building was located on the rear of the lot where the present stone church now stands. It was our lot many years afterwards to purchase the old building. We took one-half and made a stable, which is at present owned by David Rothchild. It stands in the rear of his present dwelling on Eighth steet. There seems to be a singular coincidence that the two first buildings of our city which were used for religious worship should each have been converted into a stable.

There stands an old frame building on the rear of the lot occupied by Dr. Graham's drug store. This building was originally erected at Prairie du Chien and used for a Catholic church. It was taken down and rafted down the river under the direction of the Catholic Bishop, Loras, I think in the year 1842. The Catholic congregation did not number more than half a dozen at that time. But the missionary spirit of their bishop provided them with a church. This church was used for many years until St. Mathias was built.

The Presbyterians had a church organization, but no building of their own. They held meetings in the Episcopal church. Their old bell was a present from an Eastern foundry and was placed on the roof of the little side vestry room. The bell was removed to their first church on Mulberry street east of the court-house, the walls of which are still standing and used for blacksmith shops. This bell was one of two bells 
sent to Iowa. The other passed into history as Hummer's bell at Iowa City.

The Congregational society erected a church on the hill, as it then was, near where Mr. Semple's dwelling now stands, on the corner of Fourth and Sycamore streets. This was a sinall brick building about twenty by forty feet. It had a rough wooden bell-tower erected on the back or rear end, which gave it the name of the "stern-wheel church." In this tower was hung the bell that now calls the Congregational people together. It is the oldest bell in our city. I am not able to give its history. It is sufficient to say we obeyed its call to meeting way back in the forties.

The Presbyterian bell that came here earlier was broken and removed six or eight years ago. The Catholic church had a small bell at a very early day. I should think it would weigh fifty pounds, and it was possibly the first in town. It was afterward mounted on the old Number One school-house and used for a school-bell. Very likely some of our hearers have watched its motion for fear of being tardy. We say watched its motion, for it was mounted on the top of the high tower. One could see it further than it could be heard. It was finally burned with the school-house and rendered worthless as a bell.

The Congregational church was the progressive church of the town. The other churches charged it with being aristocratic, as they considered that it rather infringed on their territory, but the attendance proved it to be rather a good society. The exterior of the building looked like a country schoolhouse. We well recollect how the inside looked at the time of our first visit. We had frequently attended the Methodist meeting where the main aisle was the dividing line between the sexes, at least during meeting time, the men occupying the right and the women the left side. It never entered our mind there could be any other manner of seating. We went early. The sexton was at the rear, ringing the bell, when we entered. The room was empty and we sat down in the end, 
furtherest from the aisle, of a seat on the right side near the middle of the church, not thinking but we would be among the men. In a short time in walked Hon. Stephen Whicher and wife, Mrs. Whicher sitting down close to us to make room for others who eame. Very soon the seats were full and we were the only boy in that part of the church, sitting among the substantial ladies of the church. We were considerably embarrassed at getting into the wrong pew, and did not make that mistake a second time.

The four described churches may well be called the pioneer churches, as no others were erected for some time afterward. The Baptists had a church organization, but did not build until 1846 or 1847 . We remember working on the interior of their church building in the winter of $1847-48$. I think they had oceupied the basement for church purposes for at least a year. The Baptists had a preacher named Seely, a very small man in stature, but a large man in expectations. We recollect attending one of his missionary meetings at Drury's Landing. It was a beautiful summer afternoon. While Rev. Seely was discoursing in the house to the women, the men stayed outside. On one side of the door, in the shade, four of the ungodly amused themselves in playing cards. On the other side the remainder were engaged in pitching hor'se shoes. Rev. Seely did not continue his missionary work at Drury's Landing much longer.

As the newcomer wandered toward the northern part of the town the court-house and jail would attract his attention. The court-house was built in $\mathbf{1 8 4 0}$ with the proceeds from the sale of lots on the commissioners' quarter, as it was called. This was a quarter-section of land donated to connties to sell, the proceeds to be applied in public buildings. The court-house, as built then, was almost identical with the front part of the present one, although the walls were once burned out and the wood-work rebuilt. The ground in front of it has been con- 
siderably filled up, so much so as to bury four or five stone steps that run along the front porch.

The jail has disappeared. It was located on the west corner of the court-honse square. A brief description of its architecture will not be found out of place. A wooden building $20 \times 40$ feet, two stories high, with an outside stairway leading up to the narrow front door in the second story. The building was erected in 1838 or '39. It was built of oak timber $12 \times 12$ inches, notched together at the corners and made of two thicknesses with a space of 10 inches between filled with broken stone. The inside wall of timber was lined with two inch plank having a twenty penny nail driven in at every square inch; the top and bottom of the first story being lined with the same. The jailor occupied the second story. Communication was held between the two stories through a trap door and by use of a ladder let down through the hole. When once in, the prisoner was considered tolerably safe. We are of the opinion that a larger percentage escapes from the present structure than ever did from that old log jail. We removed this old jail in the spring of 1857 . We still preserve the old key, weighing about a pound, in our cabinet, as a euriosity.

On the west corner of Fourth and Mulberry streets stands a three-story brick building. The two upper stories of the front part were built by Mr. Fred Miller in the year 1848 and called the Muscatine Hotel. This was the farmers' tavern of the town. It was a stopping place for the farmer when he brought his produce to market. In those days Bloomington was the frontier market place of the west. Produce from Johnson, Linn, Cedar and Benton counties found an outlet at Bloomington. When the farmer brought in his load of produce for 40 or 50 miles, he generally stopped at the first place, which was Miller's. He gave them plenty to eat, but not a particle of style. It was no uncommon occurrence to see twenty or thirty teams here at one time. On one of these accasions his large 
stable took fire and several farmers' horses were burned. When the railroad began to carry on the business of the "back counties" this hotel was no longer needed.

Within the town limits there were two or three mills. The first one built was a water mill, owned by David $R$. and Asberry O. Warfield. It stood on Mad Creek about 100 feet above Ninth street bridge. The dam was some 300 feet above the mill. This dam washed out at least three or four times. This mill sawed a considerable amount of lumber. It passed into the Brookes Brothers' hands and was run with profit to the owners until the big flood of 1851, when the dam washed ont so completely it was never rebuilt.

In the spring of $1843 \mathrm{~J}$. M. Barlow erected a very creditable steam flouring mill. It stood on the west corner of Second and Sycamore streets, where Clapp's hardware store now stands. This was a great improvement to Bloomington. This mill had for miller, John Seely, well remembered by many of our eitizens, and Zephiniah Washburn, one of Muscatine's early mayors, was fireman. The story of his election runs about this way: Politics did not enter into the contest; everybody was permitted to run just as well as he could. The "boys" got Zeph's name announced, and some of the hightoned society talked quite contemptibly of their candidate. But the "boys" went to work, and Zeph was electerl. After election the boys went to the mill, and taking him to the harness shop they got a lot of brushes and brushed him off. They told him that he was Mayor, and that he must reflect credit on the office.

On the south side of Second street, near where the railroad water tank now stands, there stood a steam saw mill which was first erected at Geneva, three miles up the river, and removed to Bloomington. It had been operated by different parties. John G. Deshler and John Vanatta were among the early owners. John Vanatta was a large-sized, heavy-built man, a eaptain in the Black Hawk war, and was well calcu- 
lated to fight his way through everything. His partner, a much younger man, was six feet high, square built, weighing abont 200 pounds and struck out well at the shoulder-in fact, a scientific boxer. One day they had a disagreement. Vanatta thought he would whip Deshler (the most common way of settling disputes in those days). Deshler was willing, so Vanatta started for Deshler, who kept backing off and hitting in the face. In a short time Vanatta was the worst punished man in town, without being able to touch Deshler. The fight furnished material for local talk for some time.

At another date this mill was owned by Robert and Samuel Kinney. Sam tended to getting in the logs and the outside work; Bob to running the engine and tending the fires. The boiler was old and leaky. One day it sprung a leak over the fire, the water ran down into the hot ashes and completely dusted the engineer, Bob, a tat, clumsy old fellow. He started to run, when, falling down on his hands and feet, he went on all fours, shouting; "Sam, Sam! run, the boiler is burst!" Sam, seeing the dust and ashes, joined in the race. The panic spread to the hands, and there was a general tumbling among the logs. This boiler was shortly replaced by another. The mill was afterwards converted into a stave and barrel factory, and was lastly worked by Coe \& Wells, but has long since disappeared.

The first lumber yard was started by F. H. Stone and Jack Richman, in the fall of 1839 . They purchased a hard wood raft of lumber that was sawed on the Maquoketa river, in all about 60,000 feet. It was composed of black walnut, oak and linn. They had the privilege of buyiug one-half or all. Stone asked Henry Reece, a carpenter, what kind would sell the best if they should take but one-half the raft. Reece said: "Take the walnut; it will all be wanted for coffins." It was quite sickly in those times. They took it all, and while it was being carried ont they had a shed erected to sit under and count the boards, the lumber having been measured and 
marked in the mill before rafting. Stone worked one day and had the ague the next, when Richman, who had it, but on alternate days, took his place, which was a great accommodation to their business.

One of the most noted places of resort was Tiley Smalley's blacksmith shop. It was the gymnasium of the town. Here the Hon. Ralph P. Lowe, his law partner, John G. Deshler, Michael Greene, Ozra Phelps, "Pap Matthews," (Hiram Matthews) Reuben Warren and a dozen others of less muscular ability, met to test their strength in wrestling, jumping, lifting and other tests of strength. One could not pass the shop, that stood near where Dillaway's store now stands, without finding from six to twelve either engaged in such tests of strength or listening to some story from "Pap Matthews," who was an expert in this line.

\section{EARLY SETTLERS.}

WHERE AND HOW THEX LIVED BEFORE 1840.

BY J. P. WALTON.

Read bejore the Muscatine Academy of Science Monday evening, Dec. 6, 1880.

IN the spring of 1838 , when the Ishnoppe, or Indian, took his final departure, the white settler, called by the Indian "Chemockeman," had made quite a stride toward the development of this part of the Black Hawk Purchase. Within a radius of a dozen miles of Bloomington, now Muscatine, at least six or eight promising towns were started. At the mouth of Pine Creek the town of Montpelier was located. It had the first post-office in this county. Letter's received at this office were directed; Iowa Post-office, Black Hawk Purchase, Wisconsin Territory, and nearly all had twenty-five cents postage charged against them. Montpelier had a grocery store, and, like all the groceries of that day, whisky was one of the most important articles, tobacco next, and with salt, coffee, sugar and molasses the store was first-class. 
Copyright of Annals of Iowa is the property of State of Iowa, by \& through the State Historical Society of Iowa and its content may not be copied or emailed to multiple sites or posted to a listserv without the copyright holder's express written permission. However, users may print, download, or email articles for individual use. 